\title{
A NEW SPECIES OF ZYGOGYNUM (WINTERACEAE) FROM NEW CALEDONIA
}

\author{
WIM VINK \\ Nationaal Herbarium Nederland, Universiteit Leiden branch, \\ P.O. Box 9514, 2300 RA Leiden, The Netherlands
}

SUMMARY

Zygogynum fraterculum, a new species of Zygogynum is described and illustrated.

Key words: Winteraceae, Zygogynum, New Caledonia.

\section{Zygogynum fraterculum Vink, spec. nov. - Fig. 1,2}

A Zygogyno cristato Vink foliis parvioribus tenuoribus, loculis antherarum discretis, stigmatibus decurrentibus adaxialibus differt. - Typus: McPherson \& Van der Werff 17859 (holo L; iso MO n.v.).

Treelet 3-8 m high. Branchlets rather slender; dry epidermis blackish brown, longitudinally wrinkled, cells laterally distinct, almost flat. Cataphylls (strongly reduced leaves), but usually their scars, between and below the leaves. Leaves scattered. Petioles $0.5-1.1 \mathrm{~cm}$ long, flat or proximally slightly canaliculate above, rounded to triangular below. Blade narrowly obovate, $1.8-5.6$ by $0.6-1.7 \mathrm{~cm}$, thinly coriaceous; apex broadly rounded, rarely obtuse; base attenuate; in sicco margins recurved; midrib flat above, slightly raised to prominent and rounded to triangular below; nerves at the middle of the blade at an angle of $55-65^{\circ}\left(-80^{\circ}\right)$ to the midrib, faint to prominulous above, faint to inconspicuous below. On lower leaf surface only stomata grey. Inflorescences with $0(-6)$ bract scars below lowest partial inflorescence; partial inflorescences 1-3, 1-flowered. Only scars of bracts seen. Pedicels flattened, often apically somewhat broadened, $35-55 \mathrm{~mm}$ long, smooth. Calyx ruptured irregularly into 2 or 3(-5) lobes, rather thick to rather thin, patent, 3-4 mm long. Corolla: 4 or 5 outer petals for $0.5-0.8$ of their length connate into a continuous ring which upon anthesis ruptures along slightly thinner areas demarcating the petals into ovate lobes $10-15$ by $4-9 \mathrm{~mm}$; inner petals $8-11$, free, elliptic to obovate, towards stamens decreasing in size, innermost ones 5.5 by $3 \mathrm{~mm}$. All petals especially on adaxial side micropapillate by high-convex cells; brachysclereids not seen. Stamens 59-81,3-5 mm long, distal stamens longer than proximal ones; filaments obovoid to rod-shaped, (partly) micropapillate by high-convex cells; thecae apical, at the median touching but distinctly demarcated, at $40-120^{\circ}$ to each other. Pollen in tetrads; exine reticulate. Carpels $10-14$, free, $3-3.5$ by $2.5-3.5$ by $1.5-2 \mathrm{~mm}$; apex long, straight to convex; stigma rather broad, abaxially as long as to slightly longer than carpel apex, adaxially after a sharp angle descending over 


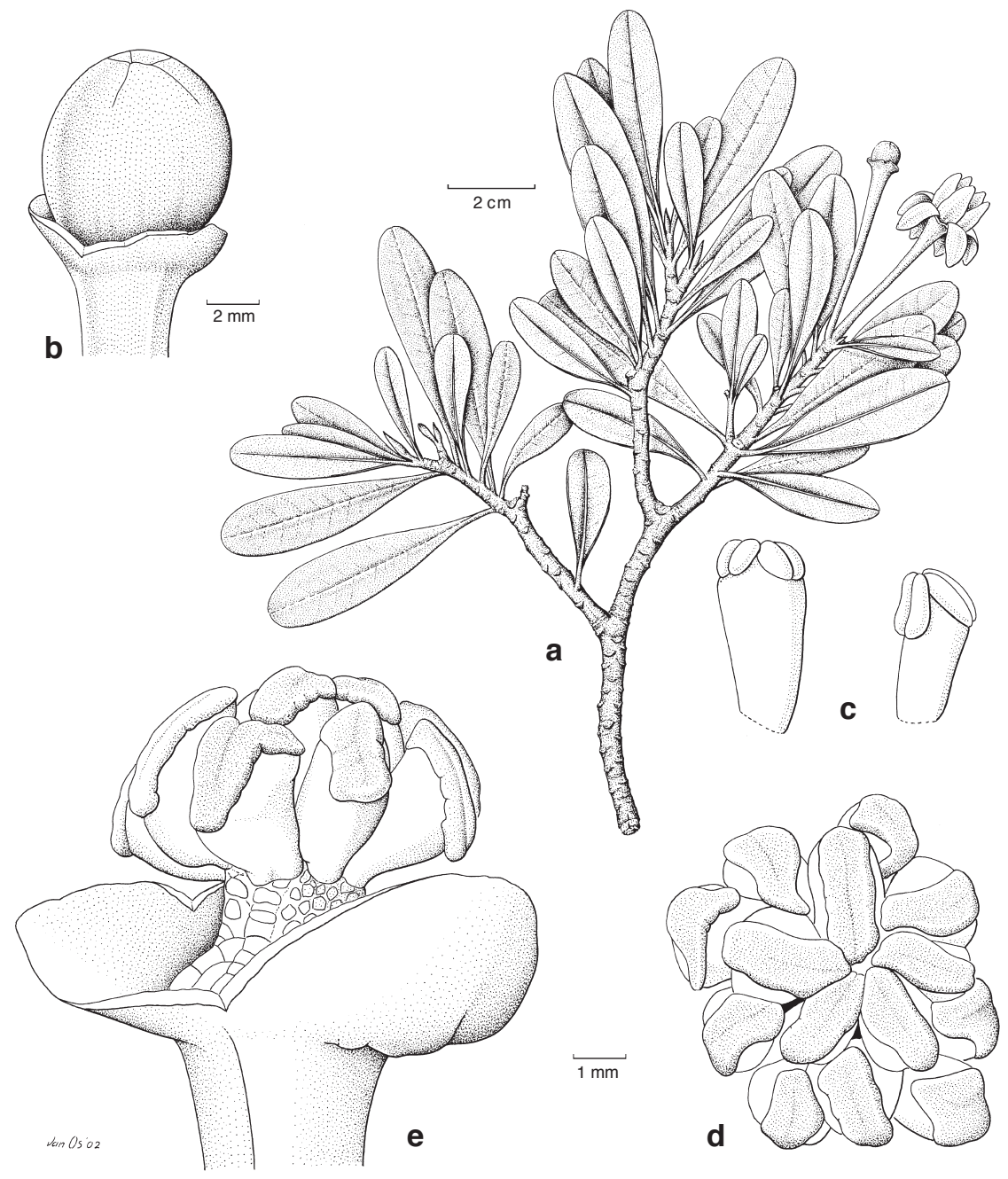

Fig. 1. Zygogynum fraterculum Vink. a. Habit; b. flower bud; c. two stamens, abaxially; d. carpels of old flower, apically; e. the same, laterally (all: McPherson \& Van der Werff 17859).

$0.6-0.8$ of the adaxial carpel side; placentas plate-like, apical-ventral; ovules $22-32$, in one crowded row per placenta and often in the centre of a curved row with prolonged funicles. Fruits unknown. Leaf anatomy: Lamina 300-400 $\mu \mathrm{m}$ thick. Adaxial epidermis 37-50 $\mu \mathrm{m}$; adaxial cuticle smooth, 7.5-10 $\mu \mathrm{m}$, underlying cell wall $1.5 \mu \mathrm{m}$. Abaxial epidermis $25-28 \mu \mathrm{m}$; abaxial cuticle $2.5-5 \mu \mathrm{m}$, underlying cell wall $3 \mu \mathrm{m}$; alveolar material only over stomata. Stomatal plugs $5-10 \mu$ m below surface of epidermis. Palisade parenchyma not developed; in mesophyll cell walls slightly lignified in abaxial half. Brachysclereids almost always solitary, infrequent. Polygonal crystals, druses, and intergrades, 7.5-10 $\mu \mathrm{m}$ in diam., scattered in mesophyll; globose to rod-shaped crystals $2-2.5 \mu \mathrm{m}$ long very rare. Oil cells $60-80 \mu \mathrm{m}$ in diam. very frequent in mesophyll. 

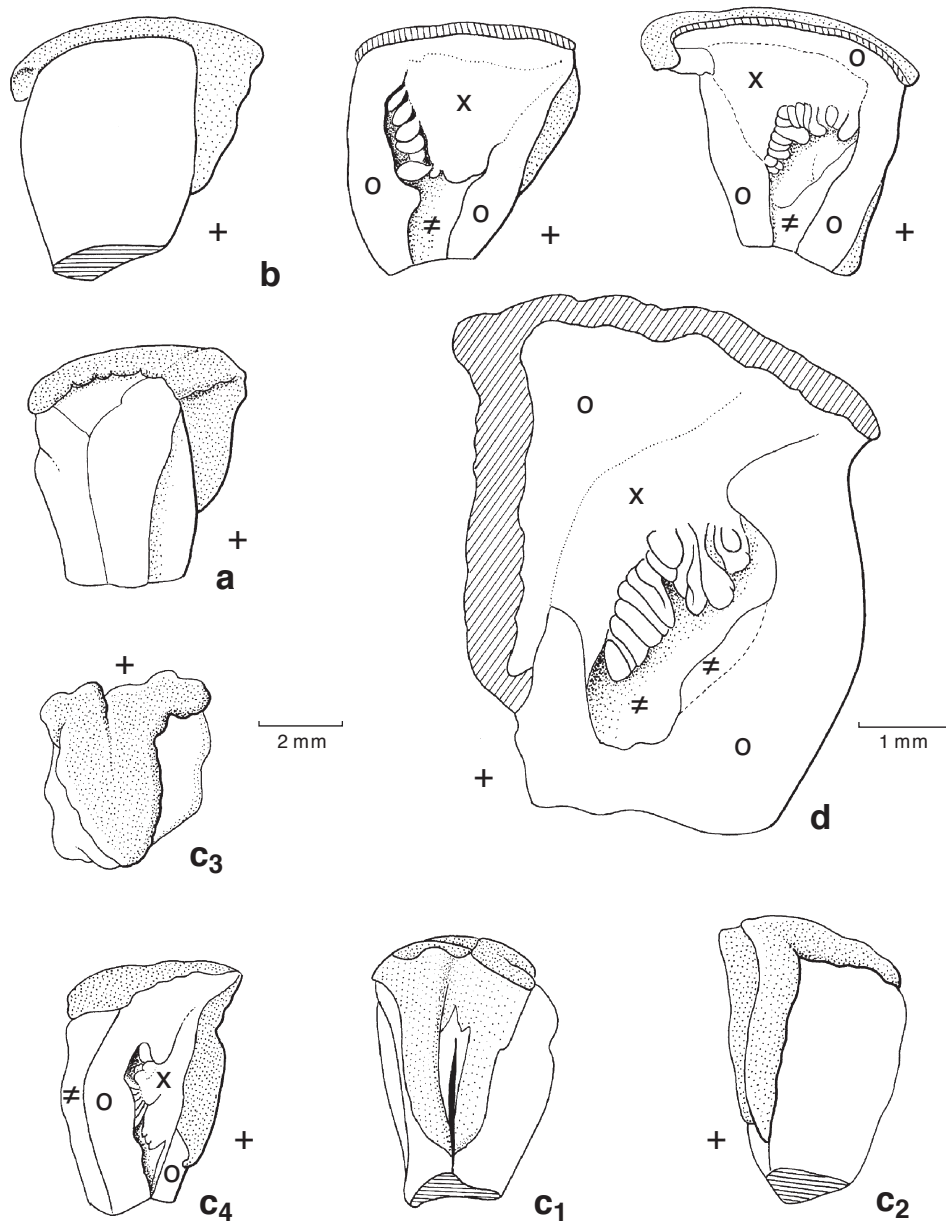

Fig. 2.Zygogynum fraterculum Vink. Carpels. a. Lateral view; impressions by adjoining carpels, also on descending part of stigma; b. other carpel, with longisections, locule extending to base, placentas differing in outline; $c$. carpel with open ventral slit: $c_{1}=$ ventrally; $c_{2}=$ laterally; $c_{3}=$ apically; $\mathrm{c}_{4}=$ longisection; $\mathrm{d}$. longisection slightly off-centre showing bulging locule wall opposite ovules and prolonged funicles in centre of placenta. $-+=$ axial side; $\mathbf{x}=$ placenta; $\mathbf{o}=$ sectioned or torn tissue; $\neq=$ original surfaces; dotted or hatched: stigma (all: McPherson \& Van der Werff 17859).

Field notes - Tree $5 \mathrm{~m}$, others seen 3-8 m. Corolla white, stamens yellow, pistils green.

Distribution - Only known from the type: New Caledonia, Mt Panié, above Haut Coulna, on SW forested slopes, 1250-1530 m altitude. Flowering: November.

Notes - In its leaves this species (fraterculus $=$ little brother) is a smaller edition of Z. cristatum Vink (Vink, 1985); its flowers are of about equal size. However, there are important differences: the thecae are distinctly separate (vs. confluent) and the long stigma descends on the adaxial side of the carpel (vs. confined to the carpel apex). Zygogynum cristatum occurs on ultrabasic soils, whereas the present species does not. 
In bud the tips of the connate petals are, if four, in two more or less distinct decussate pairs. The outer pair of these may be in the sagittal as well as in the median plane of the flower. According to Doust (2000) in Zygogynum s.s. the first pair of outer petals is lateral, that is in the sagittal plane.

The extension of the stigma over the ventral side of the carpel is a rare phenomenon in Zygogynum and is thus far only known in Z. megacarpum (A.C. Sm.) Vink (Bailey \& Nast, 1943, f. 21) and Z. tanyostigma Vink (Vink, 1993, pl. 35, f. 10). In these species the stigma terminates almost at the base of the carpel, in Z. fraterculum the stigma ends up distinctly above the carpel base.

Fig. 2c depicts a deviating carpel. In this case the adaxial carpel rims are not coherent but diverge in the middle, showing an open slit; however, at the apex of the carpel the slit is closed and sealed off by the stigma.

The ovules are inserted in a single row on each placenta. In places where the ovules are crowded, e.g. because of a curvature of the placenta, the funicles are elongated and bring the ovules in a more spacious position, out of line (Fig. 2d). Elongated funicles are found in several species of Zygogynum.

The pollen is discussed and figured by Van der Ham \& Van Heuven (2002).

The position of $Z$. fraterculum within Zygogynum s.l. can be inferred from Table 1 in Vink, 1985. There it takes the same position as Z. pauciflorum ('B. pauciflora'), intermediate between the Bubbia and Zygogynum s.s. types.

In this table Z. tanyostigma fits in with Z. howeanum ('B. howeana'), except for the solitary carpels.

\section{ACKNOWLEDGEMENTS}

Dr. G. McPherson kindly put the material of this new species at my disposal. Dr. J.F. Veldkamp checked the Latin diagnosis. J.H. van Os drew the habit and nicely inked the drawings.

\section{REFERENCES}

Bailey, I.W. \& C.G. Nast. 1943. The comparative morphology of the Winteraceae. II. Carpels. J. Arnold Arbor. 24: 472-481.

Doust, A.N. 2000. Comparative floral ontogeny in Winteraceae. Ann. Missouri Bot. Gard. 87: $366-379$.

Van der Ham, R. \& B.J. van Heuven. 2002. Evolutionary trends in Winteraceae pollen. Grana 41: 4-9.

Vink, W. 1985. The Winteraceae of the Old World. V. Exospermum links Bubbia to Zygogynum. Blumea 31: 39-55.

Vink, W. 1993. Winteraceae. Fl. Nouvelle-Calédonie 19: 90-171. 